\title{
New data on the first human settlements in western Trentino: The site of Pozza Lavino in the Ledro valley (Trentino, Italy)
}

\author{
Luca Scoz a, *, Fabio Cavulli ${ }^{b}$, Alessandro Fedrigotti a , Stefano Neri a , Annaluisa Pedrotti ${ }^{b}$, \\ Giampaolo Dalmeri ${ }^{\text {a }}$
}

a Muse - Museo delle Scienze di Trento, Corso del Lavoro e della Scienza, 3, I-38123 Trento, Italy

${ }^{\mathrm{b}}$ Department of Humanities, University of Trento, Via T. Gar, 14, I-38122 Trento, Italy

\section{A R T I C L E I N F O}

Article history:

Available online $\mathrm{xxx}$

\section{Keywords:}

Mesolithic

Sauveterrian

Castelnovian

Neolithic

High altitude

Northern Italy

\begin{abstract}
A B S T R A C T
Until 2011, the Ledro valley (Trentino, northern Italy) was known only for the pile-dwelling site of Molina di Ledro, dating to the Bronze Age. During 2011, a survey campaign was carried out in the Ledro valley by the Museo delle Palafitte del Lago di Ledro to check for the presence of further prehistoric archaeological sites. The surveys, using both field walking and remote sensing analyses, identified 15 archaeological sites. One of these is Pozza Lavino, on Mount Tremalzo at $1800 \mathrm{~m}$ asl, dating to the Mesolithic. This new site is significant because in all of western Trentino only four other Mesolithic sites are known, while in the east of the province there are more than 200. Recent research shows that this is not a problem of the morphology of the landscape or the "visibility" of the archaeological evidence, but, rather, the gap is mainly due to the different intensities of research to date. At the site of Pozza Lavino some scattered pottery fragments also suggest another occupational phase after the Mesolithic. Two radiocarbon determinations and two arrowheads indicate a Middle/Late Neolithic presence: this is particularly exceptional because no other Neolithic site in Trentino is above $1000 \mathrm{~m}$ asl. The third remarkable aspect of this site is the presence of four double-backed points typologically dated to the Epigravettian. The excavation is still in progress and so here we can provide only some preliminary results and thoughts. The sites and the deposit under excavation testify to a Mesolithic occupation in the western Trentino region that had, until almost literally yesterday, been a black hole, or at best a sparsely occupied area, in archaeological maps. The new evidence, linked to the known finds in the Brescia pre-Alps, also gives support to the idea of a new route linking the area to the Po valley. The Mesolithic and Neolithic remains of Pozza Lavino open new horizons for the study of the Mesolithic and Neolithic at high altitude and our research at this settlement has already begun to shed new light on the behaviour and settlement strategies of our prehistoric ancestors in the mountains of western Trentino.
\end{abstract}

(c) 2015 Elsevier Ltd and INQUA. All rights reserved.

\section{Introduction: state of the art}

Until 2011, the Ledro valley was known only for the piledwelling site of Molina di Ledro, dating to the Bronze Age (Battaglia, 1943; Rageth, 1974; Leonardi et al., 1981). This prehistoric settlement has been included in the UNESCO World Heritage List since 2012, together with another 110 sites of similar type all around the Alps. The site of Molina di Ledro seemed to be the only evidence of prehistoric activity in the valley.

\footnotetext{
* Corresponding author.

E-mail addresses: luca.scoz@muse.it (L. Scoz), fabio.cavulli@lett.unitn.it (F. Cavulli), alessandro.fedrigotti@muse.it (A. Fedrigotti), stefano.neri@muse.it (S. Neri), annaluisa.pedrotti@lett.unitn.it (A. Pedrotti), giampaolo.dalmeri@muse.it (G. Dalmeri).
}

At a regional scale, the first human presence in Trentino is dated to the Middle Palaeolithic: scattered flint tools are found at those altitudes not covered by ice during the last glaciation. Epigravettian sites can be found in the southeast part of the region, the most important being the Dalmeri rock-shelter with its painted stones (Dalmeri et al., 2009). Four other Epigravettian sites with archaeological deposits - Le Regole (Dalmeri et al., 2004), Andalo (Guerreschi, 1984), Terlago (Dalmeri, 1993) and Viotte del Bondone (Bagolini and Guerreschi, 1978) - are located in the northwest of the region, near the main valley of Trentino, that of the Adige. Another Epigravettian and Early Mesolithic site has recently been identified near the northern shore of Lake Garda (at an altitude of $85 \mathrm{~m}$ asl). The excavation, started in 2013, is still in progress (Mottes et al., 2014). As regards the Mesolithic, in the last fifty years, hundreds of Mesolithic finds have been discovered in Trentino, at high 


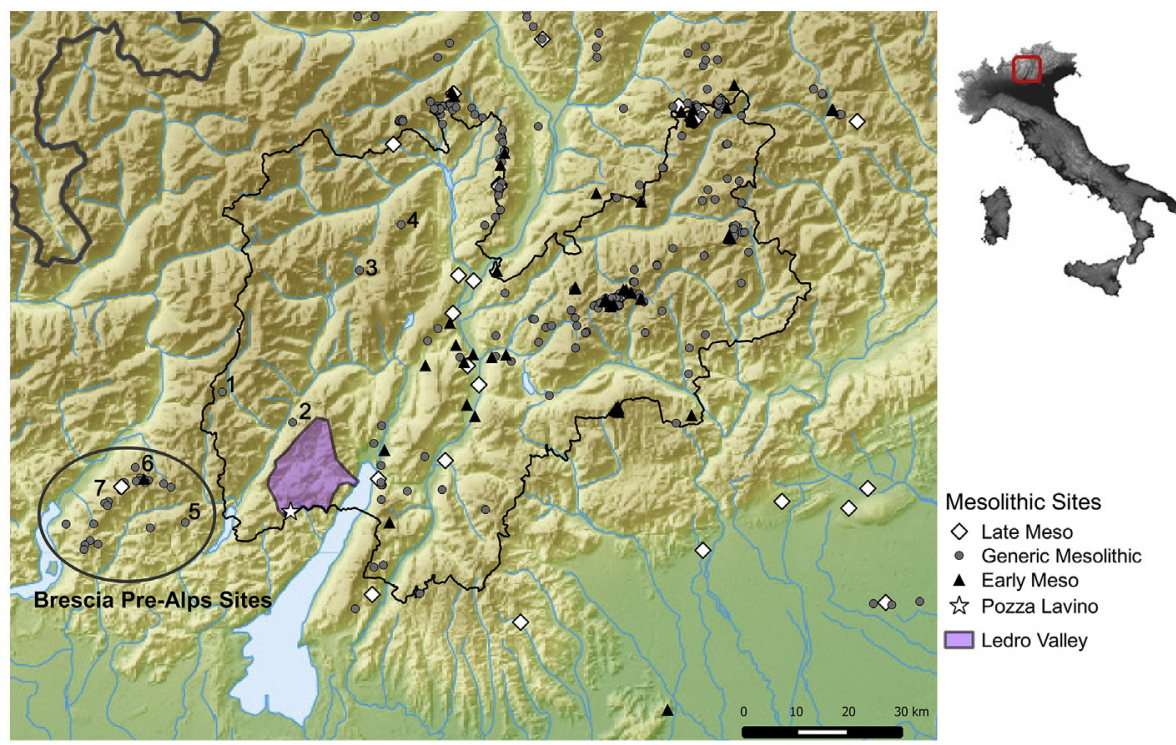

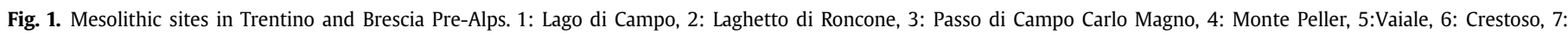
Rondeneto. Background map by Lencer, CC licence.

altitude as well as in the valley bottoms (Dalmeri et al., 2001). However, few are located at those mid-level altitudes where archaeological visibility is limited (Cavulli et al., 2011) and the spatial distribution of the evidence is not uniform (Fig. 1). More than 200 Mesolithic sites are located in eastern Trentino or close to the Adige Valley and only 4 on the western side of Lake Garda, where the Ledro valley lies (Kompatscher and Hrozny Kompatscher, 2007; Cavulli and Grimaldi, 2009; Cavulli et al., 2011; Franco, 2011). For these four sites, no stratigraphic information is available because they have not been excavated (Passo di Campo Carlo Magno, Laghetto di Roncone e Lago di Campo; Bagolini et al., 1978; Dalmeri, 1985a, 1985b, 1985c). Not far from the Ledro valley, beyond the southwest regional border, some Mesolithic sites have been found in the Brescia pre-Alps and have been excavated by Paolo Biagi (for example: Laghi di Ravenole, Laghetto di Dasdana, Vaiale, Rondeneto, Crestoso; Biagi, 1976; Biagi, 1992; Baroni and Biagi, 1997; Biagi, 1980, 2002; Biagi and Starnini, 2015). This group of sites could indicate a link between the evidence of Mesolithic activity in the Po Valley and that in the Alpine region, a northward link into the Alps comparable to those of the Adige Valley and Lagorai-Primiero. Also the first Castelnovian site discovered in Italy, Fienile Rossino, lies in the Brescia Pre-Alps (Biagi, 1972; Biagi and Cremaschi, 1978, 1980; Accorsi et al., 1987).

The most important Neolithic sites in Trentino are in the Adige valley (Pedrotti, 2001a,b) but there is now new, interesting, evidence from the northern shore of Lake Garda (Mottes, 2013). The first Early Neolithic settlements are situated in the same rockshelters that were occupied in the Late Mesolithic. However, looking at ${ }^{14} \mathrm{C}$ determinations, all the Mesolithic sites at high altitude seem to have been deserted and all the Neolithic evidence is found below $800 \mathrm{~m}$ asl. Scant evidence of Neolithic presence is known in western Trentino: just Doss Cingol, near the village of Storo, where some pottery fragments were found in 1981 (Dalmeri, 1982). A renewed economic interest in the mountain environment can be detected beginning in the later phases of the Neolithic and during the Copper Age, possibly connected to pastoral activities (Bagolini and Pedrotti, 1992; Mottes and Nicolis, 2002; Marzatico, 2007; Mottes et al., 2009; Visentin et al, 2015). Beyond the regional border, near the Ledro valley, a Neolithic site was discovered in the early 20th century (Cozzaglio, 1934).

The Bronze Age site on the Lake Ledro shore, discovered in 1929, is one of the most important pile-dwelling settlements in the Alps. The site is typically dated to 4000 years ago, but a carbon dating of the lower layers (although the dated sample was not found in connection with archaeological materials) dates back to the Late Neolithic (Cortesi and Leonardi, 1997).

This dating can be compared with the pollen-type sequences from the deposits in Lake Ledro studied by Michel Magny and colleagues in 2012. Anthropogenic indicators, dated from 8000 to 6000 years before present, seem to indicate a human presence in the valley during the Neolithic period (Magny et al., 2012). Another important pile-dwelling site in Trentino is Fiavé: the first human presence at this site is dated to the Late Neolithic, about 3800-3600 cal. BC (Perini, 1994; Pedrotti, 2001a). Human presence at high altitude during the Bronze Age is indicated by the sites of Malga Vacil and Dosso Rotondo, not far from the Ledro valley. A very interesting example of a high altitude pastoral economy is identifiable at these sites (Bassetti et al., 2008).

Throughout the prehistory of Trentino, the west side of the region is poor in archaeological sites relative to the east. Recent research shows that this is not a problem of the morphology of the landscape or the "visibility" of the archaeological evidence (Cavulli et al., 2011). Rather, the gap is mainly due to the different rates of progress of research in the two areas: the east side has been surveyed thoroughly, while the west side has not been so intensively surveyed to date. This lack of data was the primary driver behind the current research project.

During 2011, a survey campaign was carried out in the Ledro valley by the Museo delle Palafitte del Lago di Ledro to check for the presence of further prehistoric archaeological sites. The surveys, using both field walking and remote sensing analyses, identified 15 archaeological sites and more than 200 additional points of potential archaeological interest (caves, rock-shelters, mountain passes...). One of these 15 sites is Pozza Lavino, on Monte Tremalzo, dating to the Mesolithic (Scoz et al., 2013; Scoz and Fedrigotti, 2014; Fig. 2, Table 1). 
Table 1

The new archaeological sites identified in 2001 in Ledro valley.

\begin{tabular}{|c|c|c|c|c|c|c|}
\hline ID & Site name & $\mathrm{m}$ asl & Archaeological evidence & Type & Remains & Chronology \\
\hline 1 & Cadrione & 1146 & Flint & Open-air & Scattered finds & Neolithic? Bronze Age? \\
\hline 2 & Coel de Pigole & 963 & Pottery/smelting remains & Rock-shelter & Deposit & Bronze Age \\
\hline 3 & Col Plagna & 1010 & Pottery & Hill-top & Scattered finds & Middle and Recent/Final Bronze \\
\hline 4 & Doss Castel & 912 & Pottery & Hill-top & Scattered finds & Recent/Final Bronze Age - Second Iron Age \\
\hline 5 & Doss Cerì & 729 & Pottery & Hill-top & Scattered finds & Recent/Final Bronze Age - Second Iron Age \\
\hline 6 & Molina Lungolago & 670 & Pottery & Lake-shore & Scattered finds & Early and Middle Bronze Age \\
\hline 7 & Cuel de Lana & 781 & Pottery/flint/bones & Rock-shelter & Deposit & Early and Middle Bronze Age \\
\hline 8 & Spessa-Civial & 840 & Pottery/flint & Hill-top & Scattered finds & Neolithic? Bronze Age? \\
\hline 9 & Case Boccagni & 660 & Pottery & Lake-shore & Scattered finds & Bronze Age \\
\hline 10 & Pozza Lavino & 1800 & Flint/pottery & Open-air & Deposit & Epigravettian, Mesolithic, and Neolithic \\
\hline 11 & S.Anna chiesetta & 1244 & Pottery & Open-air & Scattered finds & Iron-Bronze Age? \\
\hline 12 & Pozza Saval & 1744 & Pottery & Open-air & Scattered finds & Bronze Age? \\
\hline 13 & Passo Nota & 1205 & Pottery/flint & Open-air & Scattered finds & Prehistory (generic) \\
\hline 14 & Passo Guil & 1207 & Pottery & Open-air & Scattered finds & Prehistory (generic) \\
\hline 15 & Doss de Trat & 940 & Bronze & Hill-top & Scattered finds & Iron Age? \\
\hline
\end{tabular}

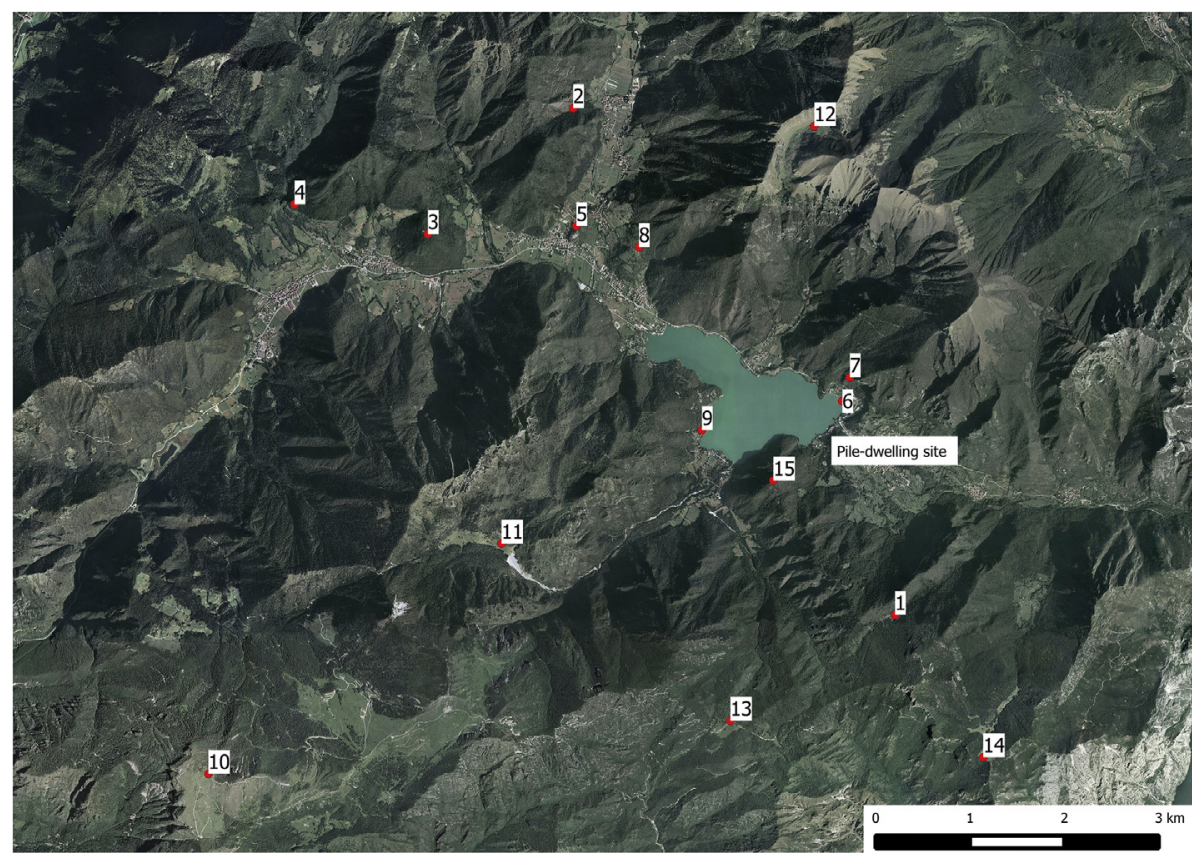

Fig. 2. The 15 new sites in Ledro valley, cf. Table 1.

Pozza Lavino is, to date, the only Mesolithic site excavated in western Trentino and provides the earliest evidence of a human presence in the mountains of this part of the region. The site gives us new information about the settlement strategies and the mobility of hunter-gatherers in this sector of the Alps. However, the excavation is still in progress and so here we can provide only some preliminary thoughts.

\section{Environmental setting}

The Ledro valley is situated in southwestern Trentino Alto-Adige (Italy), very close to the northern extremity of Lake Garda. Its main peculiarity is its east-west orientation, Alpine valleys more frequently being oriented north-south.

The valley underwent an intense glacial remodelling which left traces in the directions of both Lake Garda to the east and the Chiese Valley to the west (Cadrobbi, 1966). The valley bottom (650 $\mathrm{m}$ asl) lies about $600 \mathrm{~m}$ above the northern Lake Garda shore (65 $\mathrm{m}$ asl) and $400 \mathrm{~m}$ above the Chiese Valley. Its location has impeded access in both the ancient and the recent past: the valley is surrounded by mountains reaching ca. $1500-2200 \mathrm{~m}$ asl with relatively steep slopes and no passes below $1000 \mathrm{~m}$ asl. Lake Ledro fills most of the eastern valley bottom.

Owing to the karst nature of the valley, surface streams are extremely rare. Water mostly flows underground and collects in the lake.

The valley is poor in flint, this area being characterised by a carbonate substratum with Triassic (dolomite), Jurassic and Cretaceous limestone. Monte Baldo, on the opposite side of Lake Garda, is known for its good quality flint: the raw material of the artefacts found in Pozza Lavino probably comes from there (Bagolini and Nisi, 1976; Finotti, 1981; Dalmeri et al., 2008a).

The region of Lake Garda ( $65 \mathrm{~m}$ asl) is famous for particularly mild climatic conditions which allow the presence of Mediterranean species (Beug, 1964). However, due to its higher elevation, the vegetation in the Ledro valley is quite different. It is dominated at the lower elevations by Fagus sylvatica (beech) mixed with Abies alba (silver fir), then by Picea abies (spruce) in the higher part of the montane belt (650-1600 m), and by Pinus mugo (mountain pine), Alnus viridis (green alder), Larix decidua (larch) and Picea in the 

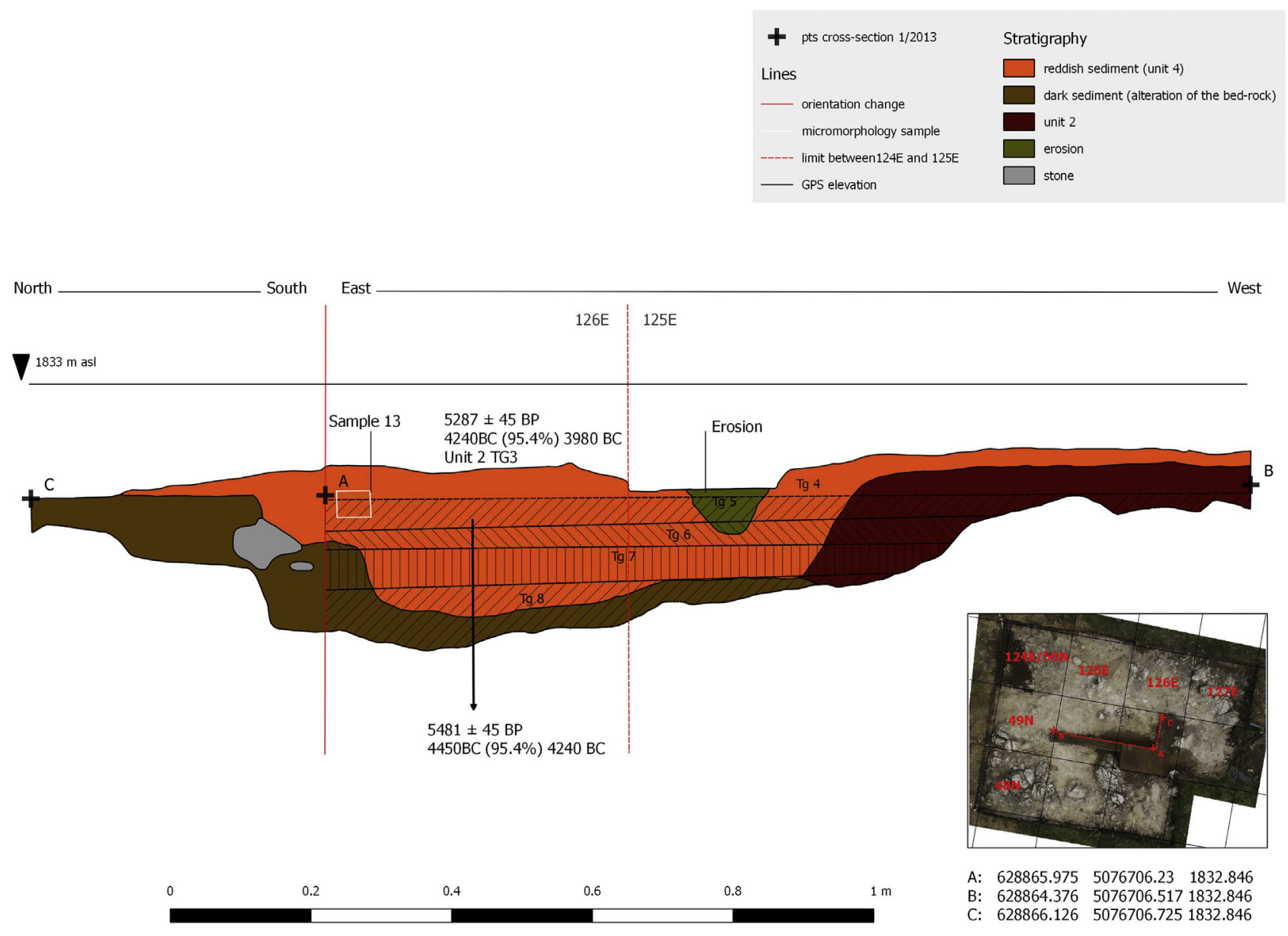

Fig. 3. Section 1, SU 4 and SU 2 (TG4-5-6-7-8) with positioning of ${ }^{14} \mathrm{C}$ and micromorphology samples.

subalpine belt (1600-2000 m). Above $2000 \mathrm{~m}$ asl, grasslands dominate (Beug, 1964; Reisigl, 2001). Generally speaking, mixed oak forests did not develop in the Ledro valley (Magny et al., 2012).

The site of Pozza Lavino is located on Monte Tremalzo (municipality of Ledro), at $1800 \mathrm{~m}$ asl, at the watershed between southwestern Trentino and Northeastern Lombardy. The slopes of Monte Tremalzo are very steep and the meadows of Pozza Lavino are the only flat land in the area. The only available water source, a little basin, is near the archaeological site and was used in the recent past to water livestock. This basin dried up fifteen years ago, but nearby a small spring continues to flow.

\section{Research methods}

Carrying out a systematic ground survey campaign in the mountainous context of the Ledro valley is impossible because of the rugged topography. Hence, topographical, geological and toponymic cartography, a 3D Lidar model and aerial photos were used to detect points of potential archaeological interest: rockshelters, saddles, water supplies, other natural resources etc. Over 150 rock-shelters were found in the toponymic atlas; little water basins and mountain passes are seen in topographical cartography; Digital Elevation Models and aerial photos show evidence of recent land-use. Some of these points of potential archaeological interest were checked by field survey in order to identify surface archaeological remains.

One of the most intriguing locales where artefacts have been found is Pozza Lavino because of the quantity of finds, the presence of an archaeological deposit and the topography of the area. The first finds came from a series of large depressions under the grass that had been accidentally revealed by the rooting behaviours of wild boars. They revealed a long-term occupation in a location with characteristics common at Mesolithic sites (a crest with a water supply at $1800 \mathrm{~m}$ asl) but in an area heretofore regarded as empty in terms of the Mesolithic occupation of Alpine territory.

To investigate a wider area (about $20 \mathrm{~m}^{2}$ ), a series of small $1 \mathrm{~m} \times 1 \mathrm{~m}$ test pits were opened and enlarged to cover wider areas as and when justified by finds. In 2012, trenches were opened on the south shore of the lake along a west-east alignment (Areas 1-5), while in subsequent years we have intensified our investigations of area 2 , which reached an extent of $18 \mathrm{~m}^{2}$ in 2014, as well as opening new small trenches around the depression (Areas 6-8). The excavation generally adopted a stratigraphic approach, based on homogeneity and continuity of sediments, from an early stage of the research but used artificial cuts (cf. Stein, 1992) to dig stratigraphic unit (henceforth SU) 2 because the layer in some areas was $40 \mathrm{~cm}$ deep. The site employed a $1 \mathrm{~m} \times 1 \mathrm{~m}$ grid and all excavated soil was passed through a $2 \mathrm{~mm}$ sieve. Sieving allowed us to collect even small debris and microliths. We used a Total Station and a DGPS (Differential Global Positioning System) to draw plans/ maps and to plot all the find positions in a 3D coordinate system. Field recording focussed on the main characteristics of both the finds (position, material, layer, inclination, traces of burning) and the stratigraphic units (components, relations with other layers, colour, area, plans and cross sections). 


\section{Discussion and results}

The 2011 survey campaign in the Ledro valley also recovered scattered pottery fragments, presumably dating to the Bronze and Iron Ages. These finds can be connected to pastoral activities in the mountains around the valley (Scoz and Fedrigotti, 2014).

Fifteen sites (Fig. 2, Table 1) were discovered during this survey campaign. Pozzo Lavino turned out to be one of the most interesting sites in terms of both the number and types of archaeological finds.

\subsection{Stratigraphy}

The stratigraphy of Pozza Lavino consists of three layers. SU 1 is directly under the grass cover and represents the modern-day soil. SU 2 is a silty-clay layer with scarce potsherds in the upper part and evidence of flint industry throughout. At the point of contact with the limestone bedrock it turns a darker brown and is termed SU 3, a layer that contains no cultural remains. SU 4 is a clayey red sediment area, the colour presumably a result of burning (rubefaction): it results from the alteration of SU 2, and has been preliminary interpreted as a hearth (Fig. 3).

\subsection{Archaelogical remains and $14 C$ determination}

The main archaeological layer, SU 2, contains 337 artefact out of a site total of 359 (Table 2): other remains come from surface survey (6 pieces); SU 4, the presumed hearth inside SU 2 (5 pieces); and SU 1 (11 pieces). SU 2 was divided into 7 artificial horizontal cuts (each $5 \mathrm{~cm}$ deep) during the excavation, known as cut $1-$ cut 7 . The main concentration of archaeological remains was in cuts 3 ( 83 pieces), 4 (87 pieces) and 5 (56 pieces) (Fig. 4).

Table 2

Total remains from SU 1, 2 and 4

\begin{tabular}{lrrllr}
\hline & Flint & Pottery & Stone & Daub & Total \\
\hline SU 1 & 9 & 2 & 0 & 0 & 11 \\
SU 2 & 315 & 17 & 2 & 3 & 337 \\
SU 4 & 5 & 0 & 0 & 0 & 5 \\
Surface & 6 & 0 & 0 & 0 & 6 \\
Total & 335 & 19 & 2 & 3 & 359 \\
\hline
\end{tabular}

Of the 359 significant artefacts collected and whose position was precisely recorded, 335 are flint, 19 pottery, 3 daub and 2 allochthonous mica schist. Other finds identified through sieving are not considered in the present work. The ceramics are quite rough, always without decoration or identifying features such as rims or handles, with the exception of an appliqué boss, and so impart little chronological information. Whether these remains pertain to the Late Neolithic or to a more recent phase is not yet clear. The study of the lithic material is still underway and so at the time of writing only preliminary observations are available (Fig. 5; Tables 2-4).

Table 3

Total lithic assemblage from SU 1, 2 and 4.

\begin{tabular}{lc}
\hline Lithic assemblage & RR number \\
\hline Debris & 130 \\
Blade & 113 \\
Flake & 63 \\
Core & 6 \\
Total & $\mathbf{3 1 2}$ \\
Retouched & 33 \\
\hline
\end{tabular}

Table 4

Total flint typology and technology from SU 1, 2 and 4. Laplace typology.

\begin{tabular}{lc}
\hline Flint tools, armatures and cores & RR number \\
\hline Trapeze & 1 \\
Truncation & 1 \\
Backed-point & 1 \\
Point & 1 \\
End-scraper & 2 \\
Triangle & 2 \\
Arrow-head & 2 \\
Burin & 2 \\
Scraper & 3 \\
Double backed-point & 4 \\
Core & 6 \\
Retouched blade & 10 \\
Total & $\mathbf{3 5}$ \\
\hline
\end{tabular}

The burned pieces constitute $70 \%$ of the total. Ten percent of the flint remains are retouched. The typology of the lithic industry is quite clear: Sauveterrian and Castelnovian facies are the most represented but there are also a few remains of a hypothetical Epigravettian phase, as well as a later Neolithic one, represented by arrowheads. Presumably, many of the unretouched blades also belong to this last period.

The four double-backed points are not comparable with the Sauveterrian ones, because of their size and thickness (Fig. 5.1; RR 70 Length: $3.32 \mathrm{~cm}$, width $0.71 \mathrm{~cm}$ thickness $0.62 \mathrm{~cm}$ ). Artefacts of this size can be compared with the double-backed points from SU 18 and SU 16 in the La Cogola rock-shelter (southeastern Trentino). Those archaeological levels are dated to the transition between the Epigravettian and the Sauveterrian (Cusinato et al., 2004; Bassetti et al., 2009). Backed points and triangular armatures (Fig. 5.3-4) attest to an Early Mesolithic phase (Laplace Gm3, Laplace, 1964; Broglio and Kozlowski, 1983, Fig. 21-9), while a Castelnovian phase is clearly attested by a trapezoidal armature comparable to the finds from Pradestel layer E (Dalmeri et al., 2008b; Franco, 2011 Fig 28-1 p. 126) (Fig. 5.5).

The arrowheads (Fig. 5.6-7) are comparable to other mountain finds from northeastern Italian sites such as: Bocca Vaiona, Malga Vacil and Monte Baldo in Trentino province (Marzatico, 2007); Mondeval de Sora (Fontana and Pasi, 2002; Visentin et al., 2015), Monte Cernera (Palmieri, 1978; Bagolini and Pedrotti, 1992), Lastoni del Formin and Malga Pradazzo in the Veneto region (Cavulli et al. 2015); Monte Guglielmo in Val Trompia (Malga Stalletti Alti and Punta Caravina) in the nearby province of Brescia (Biagi, 2002; Biagi and Starnini, 2015).

Seventy-five percent (256) of the archaeological remains were found lying horizontally, $17 \%$ (61) lying obliquely and $7 \%(24)$ in a vertical orientation. This would seem to suggest that the finds did not experience substantial displacement within the layer. However, the radiocarbon analyses show that the hearth is more recent than the flint remains above it. We must therefore suppose that a slow and limited movement of the Mesolithic artefacts down the slope occurred and resulted in them overlying the Neolithic fireplace while maintaining their horizontal orientations.

The Neolithic phase is also demonstrated by ${ }^{14} \mathrm{C}$ determinations (Table 5), the dates of SU 4-TG5 and SU 2-TG3 can be compared with the Middle and Late Neolithic sites of Isera la Torretta phase 1 (Pedrotti, 1996), Ala le Corone (Nicolis et al., 2007) and other "Square Mouth Pottery" sites of northern Italy (Bagolini and Biagi, 1990). 
Table 5

${ }^{14} \mathrm{C}$ determination by CEDAD (Centro di datazione e diagnostica), University of Salento, with software OxCal Ver. 3.10.

\begin{tabular}{|c|c|c|c|c|}
\hline Laboratory code & ID/Type of wood & Archaeological layer and square & Radiocarbon Age (BP) $/ \delta^{13} \mathrm{C}(\% 0)$ & ${ }^{14} \mathrm{C}$ Calibrated date $2 \sigma$ \\
\hline LTL14417A & PLAV CAMP8/Laburnum cfr. alpinum & US4 TG5 126E/49N & $5481 \pm 45 /-19.1 \pm 0.5$ & 4450BC (95.4\%) 4240BC \\
\hline LTL14418A & PLAVCAMP4/Coniferae & US2TG3 126E/49N & $5287 \pm 45 /-22.5 \pm 0.8$ & $4240 \mathrm{BC}(95.4 \%) 3980 \mathrm{BC}$ \\
\hline LTL14416A & PLAV CAMP10/Coniferae & US2 TG7 & $2608 \pm 35 /-20.6 \pm 0.6$ & $840 \mathrm{BC}(95.4 \%) 750 \mathrm{BC}$ \\
\hline
\end{tabular}

\section{Preliminary conclusions}

The presence of double-backed points of large size at Pozza Lavino suggests an Epigravettian phase, which is particularly interesting given the altitude of the deposit: $1800 \mathrm{~m}$ asl. Indeed, the average elevation of the Upper Palaeolithic sites in Trentino is between 1000 and $1300 \mathrm{~m}$ asl (Cavulli et al., 2011). The existence of just 4 pieces does not, however, really justify us in proposing even preliminary hypotheses.

The majority of the archaeological remains from Pozza Lavino are ascribable to the Mesolithic period, specifically the Sauveterrian and the Castelnovian facies. The altitude of $1800 \mathrm{~m}$ asl is comparable to other mountain Sauveterrian sites in the region (around $2000 \mathrm{~m}$ asl) but the geomorphological context is, as we have seen, very different. In the Ledro mountains the slopes are very steep and the Tremalzo pass area is the only small flat area of Alpine pasture. Comparable sites would be those studied by Paolo Biagi in Lombardy (in the Brescia pre-Alps). The site of Rondeneto ( $1780 \mathrm{~m}$ asl) is dated to the Boreal period by two radiocarbon dates (GrN-18252: $7710 \pm 50 \mathrm{BP}$ and GrN-18253: $7175 \pm 50 \mathrm{BP})$ and the flint assemblage is datable to the Sauveterrian period. The site of Laghetti del Crestoso (2000 m asl) is dated to the Castelnovian period by many trapezoidal armatures and four radiocarbon dates (GrN-18091: $6870 \pm 70$ BP, HAR-8871: $6790 \pm 120$ BP, Beta-35241: $7850 \pm 80$, GrN-21889: $7870 \pm$ 50; Biagi, 1992, 1997; Biagi and Starnini, 2015). Another site in this area, Vaiale, lies at an altitude of $830 \mathrm{~m}$ asl and was also inhabited again later, in the Iron Age (Biagi and Nisbet, 2008). The river Chiese, the main link between the Po valley and western Trentino through the Brescia pre-Alps, links the area studied by Paolo Biagi with the Ledro valley.

Another western Trentino gateway to approach the inner Alps from the Po plain could have been Lake Garda. However, the very steep slopes of the western shore do not allow easy passage. Considering the Adige Valley, the hypothesis of a high route passing through the Tremosine highland to reach the Riva del Garda-Arco plain (Moletta Patone and Arco via Serafini) is more concrete but, to the best of our knowledge, no sites have yet been detected.

Limiting ourselves to the available archaeological evidence, the sites in eastern Lombardy (Valle del Chiese, Val Trompia) seem to represent the first incursions of Mesolithic hunter-gatherers into

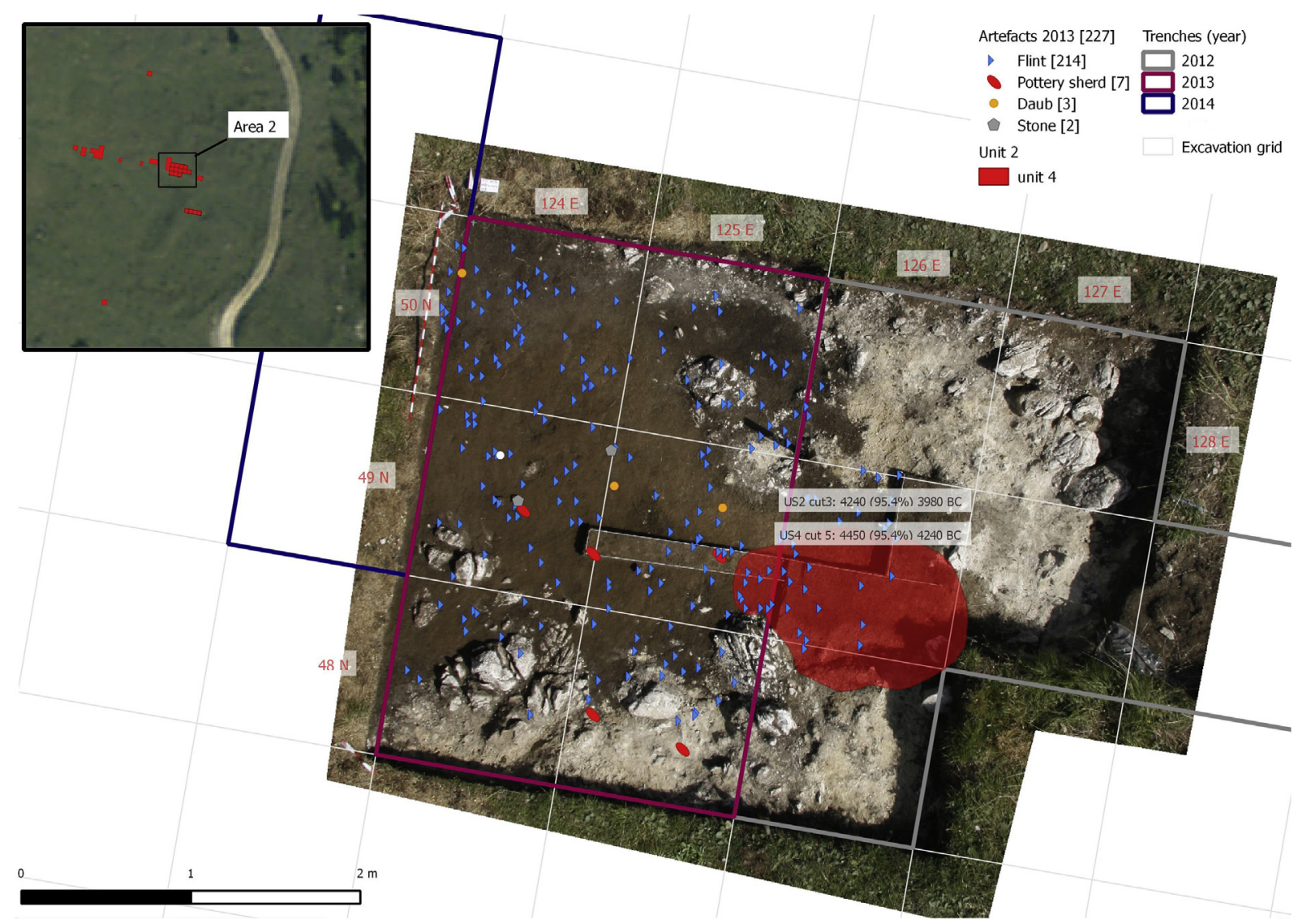

Fig. 4. Area 2 with positioning of archaeological remains, ${ }^{14} \mathrm{C}$ samples and SU 4. Trenches of 2012, 2013 and 2014. 


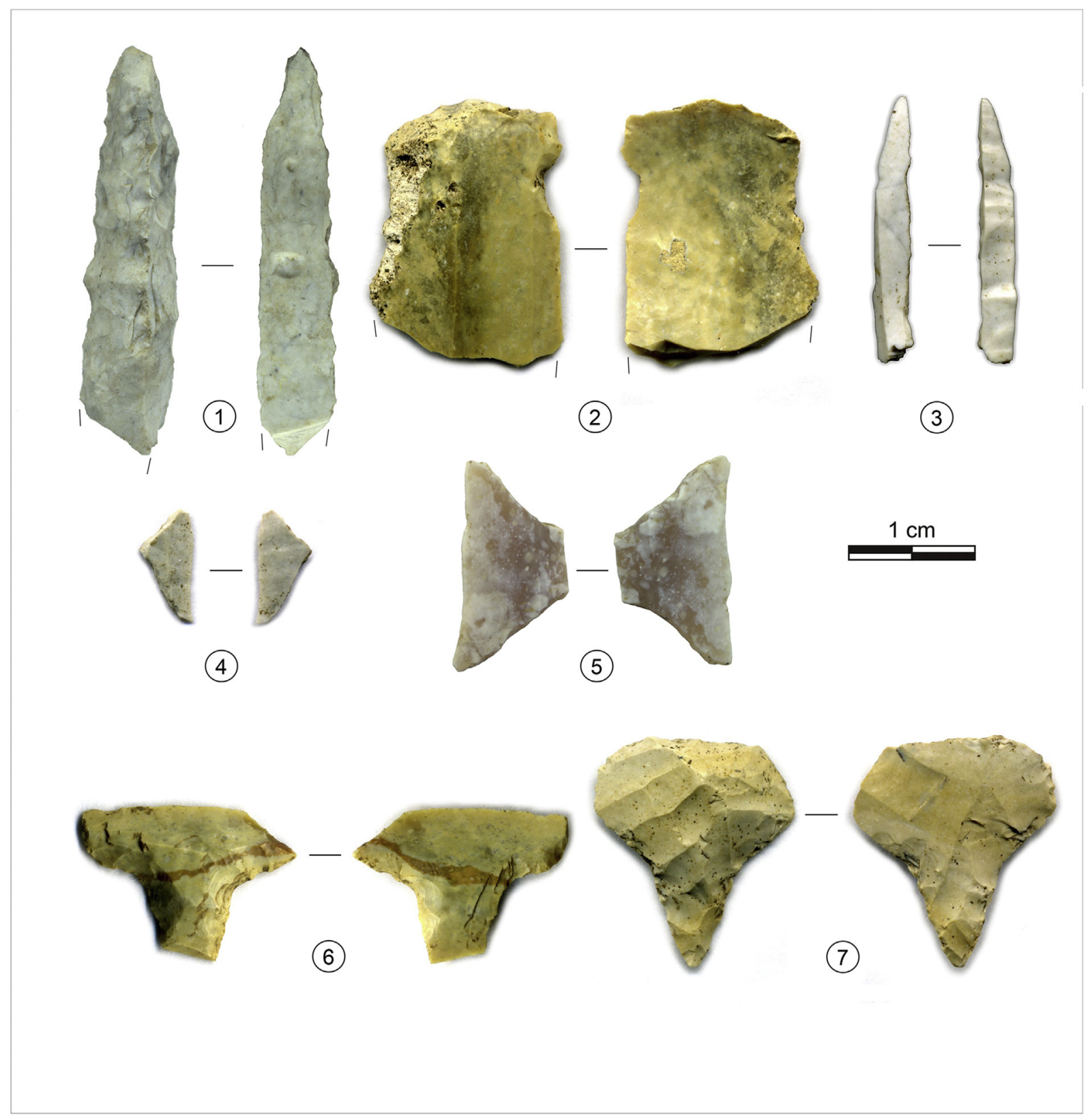

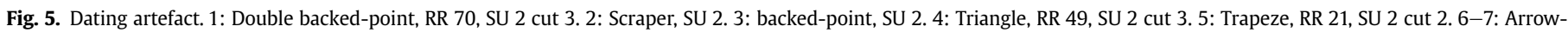
heads tranchant transversal, SU 2.

this part of the Alps and Pozza Lavino could then represent the link between those sites and the other, still scanty, evidence in western Trentino.

Further, regarding the Neolithic arrowheads, the high altitude of Pozza Lavino is surprising. No other Neolithic site in Trentino is above $800 \mathrm{~m}$ asl. But, as we wrote above, some similar scattered finds have been recovered in the area of the Dolomites (Carrer and Pedrotti, 2015; Cavulli et al., 2015). Neolithic deposits in mountain environments are known in the western Alps at Ubaye valley (France; Garcia et al., 2007), at Monte Fallére (Aosta valley, Italy; Raiteri, 2008-2009), and at Monviso (Pétrequin et al., 2013). In the Central Alps such finds are known from Silvrettagruppe (Austria; Reitmaier et al., 2013), Schnidejoch (Hafner, 2009) and Mesocco-Tec (Switzerland; Della Casa, 1995).
The most important Neolithic sites of the Adige valley are residential sites or cemeteries. In addition to the altitude, the main difference between these sites and Pozza Lavino is the purpose of the site: Pozza Lavino, in its Neolithic phase, can be compared with Malga Vacil and Dosso Rotondo, Storo (Bassetti et al., 2008), sites that have close ties with the mountain environment and resources. In fact, at the moment, the most likely hypothesis is that the Tremalzo Mountains were a hunting ground - this is the hypothesis that finds most support on the basis of the archaeological finds. However, if the pottery turns out to be Neolithic this hypothesis must be reconsidered, since ceramic artefacts are more related with residential sites.

There are no faunal remains at Pozza Lavino but the lithic assemblage and the position of the site suggest a hunting camp. The 
presence of the little water basin also supports this hypothesis because the surface water, scarce in the limestone Tremalzo mountains, would have been a natural attraction for animals.

The fifteen new sites identified in the Ledro valley testify to a human presence in various landscape contexts at various times. At the time of the pile-dwelling village, human groups also lived beyond the lakeshores. Scattered pottery fragments at the tops of some hills, in rock-shelters and at mountain passes provide evidence of a complex system of settlements and exploitation consisting of the main site in the valley bottom and functional sites with different purposes spread across the surrounding territory. The hill-top sites permitted visual control of the territory; the human presence at the mountain passes/saddles could have been related to pastoral activities; rock-shelters could have been used to corral the livestock and/or for smelting activities. These data confirm the framework already suggested by other Copper/Bronze Age sites in the Alps, from Liguria to Slovenia and Stiria. All show that mountain activities can be differentiated into categories such as transhumance, mineral exploitation, smelting, hay-making and hunting (Bagolini and Pedrotti, 1992; Küster, 1994; Oeggl, 1994; De Marinis and Pedrotti, 1997; Riedel and Tecchiati, 1997; Castelletti and Motella De Carlo, 1998; Venturino Gambari, 1998; Della Casa, 2001, 2002, 2003; Mottes and Nicolis, 2002; Maggi, 2004; Nisbet, 2004; Marzatico, 2007). An earlier human presence is also attested by the archaeological remains from Pozza Lavino. These data confirm a Middle/Late Neolithic presence in the valley and establish the time of the first human presence there as the transition between the last phase of the Upper Palaeolithic and the Sauveterrian. The absence of Neolithic and Mesolithic remains in other areas of the valley might still be the result of past research bias.

The sites and the deposit under excavation testify to a Mesolithic occupation in the western Trentino region, a region which had been something of a black hole, or, at best, a sparsely occupied area, in archaeological maps until very recently. The new evidence, linked to the known finds in the Brescia pre-Alps, gives support to the idea of a new route linking the area to the Po valley. The suggested route towards the inner Alps is parallel to, and contemporary with, and not alternative to, the already well-known ones: the Veneto preAlps and the Adige valley. The watershed position of the Pozza Lavino settlement can - and has already begun to - shed new light on the behaviour and settlement strategies of our prehistoric ancestors in the mountains of western Trentino.

\section{Acknowledgements}

This research is sponsored by "Sartori Ambienti, Soluzioni per l'ecologia, Green Technology" Via S. Andrea, 51 - Arco, Trento. Special thanks to Michele Sartori for his support and passion and to Craig Alexander for enhancing the written English of the paper.

\section{References}

Accorsi, C.A., Bandini Mazzanti, M., Biagi, P., Castelletti, l., Cremaschi, M., leoni, l., Pavarani, M., 1987. Il sito mesolitico di Sopra Fienile Rossino sull'Altopiano di Cariadeghe (Serle - Brescia). Aspetti pedostratigrafici, archeologici, antracologici e palinologici. Natura Bresciana 23, 239-292.

Bagolini, B., Biagi, P., 1990. The radiocarbon chronology of the Neolithic and Copper Age of Northern Italy. Oxford Journal of Archaeology 9, 1-23.

Bagolini, B., Guerreschi, A., 1978. Notizie preliminari sulle ricerche 1977-1978 nell'insediamento paleolitico delle Viotte di Bondone (Trento). Preistoria Alpina 14, $7-31$.

Bagolini, B., Nisi, D., 1976. Monte Baldo (Verona-Trento). Preistoria Alpina 12, 237-241.

Bagolini, B., Pedrotti, A., 1992. Vorgeschichtliche Höhen-funde im Trentino-Südtirol und im Dolomitenrum vom Spätpaläolithikum bis zu den Anfängen der Metallurgie. In: Höpfel, F., Platzer, W., Spindler, K. (Eds.), Der Mann im Eis, I. Veröffentlichungen der Universität Innsbruck, vol. 187, pp. 359-377.

Bagolini, B., Nisi, D., Tonelli, L., 1978. Passo di Campo Carlo Magno (Madonna di Campiglio, Trento). Preistoria Alpina 14, 232.
Baroni, C., Biagi, P., 1997. Excavation at the high altitude mesolithic site of Laghett del Crestoso (Bovegno,Brescia - northern Italy). In: Supplemento ai commentari dell'Ateneo di Brescia per l'anno 1997. Brescia.

Bassetti, M., Dalmeri, G., Mottes, E., Nicolis, F., 2008. La frequentazione delle alte quote nell'età del Bronzo. Il sito di Storo-Dosso Rotondo. In: Mottes, E. Nicolis, F., Zontini, G. (Eds.), Archeologia lungo il Chiese. Nuove indagini e prospettive di ricerca preistorica e protostorica in un territorio condiviso tra Trentino e Lombardia. Trento, pp. 107-127.

Bassetti, M., Cusinato, A., Dalmeri, G., Hrozny Kompatscher, M., Kompatscher, K. Wierer, U., 2009. Updating of the Final Palaeolithic-Mesolithic transition in Trentino (NE Italy). In: Proceedings of Hugo Obermaier Society. 49th Annual Meeting. Preistoria Alpina 44, pp. 121-135.

Battaglia, R., 1943. La Palafitta del Lago di Ledro nel Trentino. Memorie del Museo di Storia Naturale della Venezia Tridentina 7, 1-64.

Beug, H.J., 1964. Untersuchungen zur spätglazial en Vegetationsgeschichte im Gardaseegebiet unter besonderer Berücksichtigung der mediterranen Arten. Flora 154, 401-444.

Biagi, P., 1972. Il giacimento sopra Fienile Rossino sull'Altipiano di Cariadeghe (Serle-Brescia). Preistoria Alpina 8, 177-197.

Biagi, P., 1976. Laghi di Ravenole e Laghetto Dasdena (Brescia). Preistoria Alpina 12 262-263.

Biagi, P., 1980. Passo del Crestoso (Brescia). Preistoria Alpina 16, 144.

Biagi, P., 1992. Mesolithic exploitation of the highland zone: a case study for the southern alps. Preistoria Alpina 28 (1), 367-372.

Biagi, P., 1997. Ricerche sul Mesolitico della Valcamonica (Brescia). Bollettino del Centro Camuno di Studi Preistorici 30, 23-40.

Biagi, P., 2002. Le stazioni preistoriche di Monte Guglielmo (Gölem) e del Monte Ario in Val Trompia (Brescia). In: Commentari dell'Ateneo di Brescia per l'anno 2002 bicentenario di fondazione. Proceedings of Fondazione "Ugo da Corno" 2002, Academic year CCI, Ateneo di Brescia. Brescia, pp. 223-249.

Biagi, P., Cremaschi, M., 1978. Altopiano di Cariadeghe (Serle - Brescia). Preistoria Alpina 14, 266.

Biagi, P., Cremaschi, M., 1980. Altopiano di Cariadeghe (Serle - Brescia). Preistoria Alpina 16, 131.

Biagi, P., Nisbet, R., 2008. Gli scavi nella stazione preistorica di Vaiale in Valle Sabbia (Lavenone, Brescia). In: Mottes, E., Nicolis, F., Zontini, G. (Eds.), Archeologia lungo il Chiese. Nuove indagini e prospettive di ricerca preistorica e protostorica in un territorio condiviso tra Trentino e Lombardia. Trento, pp. 25-35.

Biagi, P., Starnini, E., 2015. Human settlement and environmental exploitation of Valcamonica-Valtrompia watershed from the beginning of the Holocene to the Middle Ages. Natura Bresciana 39, 199-209.

Broglio, A., Kozlowski, S.K., 1983. Tipologia ed evoluzione delle industrie mesolitiche di Romagnano III. Preistoria Alpina 19, 93-148.

Cadrobbi, M., 1966. Note intorno alla geologia della regione dolomitica compresa fra le valli di Ledro e d'Ampola e il lago di Garda e il ricoprimento di TremosineTignale: osservazioni, problemi e mete per nuove ricerche. Memorie dell'Accademia Patavina di Scienze Lettere ed Arti 78, 259-270.

Carrer, F., Pedrotti, A., 2015. Archeologia della pastorizia nella Alpi italiane. In: Angelucci, D.E., Carrer, F. (Eds.), Paesaggi pastorali d'alta quota in Val di Sole. Le ricerche del progetto ALPES - 2010-2014. Università degli Studi di Trento Trento, p. 24

Castelletti, L., Motella De Carlo, S., 1998. La ricerca archeobotanica preistorica e protostorica in Piemonte: risultati e prospettive. In: Proceedings of the "XXXII Riunione Scientifica Istituto Italiano di Preistoria e Protostoria: Preistoria Protostoria del Piemonte", pp. 363-373.

Cavulli, F., Grimaldi, S., 2009. Raw material and settlement strategies at the Pleistocene/Holocene boundary in Trentino (northeastern Italian Alps): a GIS approach. In: McCartan, S., Woodman, P., Schulting, R., Warren, G. (Eds.), Mesolithic Horizons: Proceedings of the $7^{\text {th }}$ International Conference on the Mesolithic in Europe. Belfast.

Cavulli, F., Carrer, F., Fedele, P., Valt, G., Cesco Frare, P., Fogliata, G., Pedrotti, A., 2015. Recenti rinvenimenti di cuspidi a ritocco piatto coprente in alta quota dal territorio bellunese: Lastoni del Formin e Malga Pradazzo. In: Proceedings of the "XLVIII Riunione scientifica Istituto Italiano di Preistoria e Protostoria: Veneto" (in press).

Cavulli, F., Grimaldi, S., Pedrotti, A., Angelucci, D.E., 2011. Toward an understanding of archaeological visibility: the case of the Trentino (southern Alps) In: van Lausen, M., Pizziolo, G., Sarti, L. (Eds.), Hidden Landscapes of Mediterranean Europe. Cultural and Methodological Biases in Pre- and Protohistoric Landscape Studies. Proceedings of the International Meeting, British Archaeological Reports International Series 2320. Archeopress, Oxford, pp. 83-94.

Cortesi, C., Leonardi, G., 1997. New radiometric data on the Molina di Ledro lakedwelling (excavations 1980 and 1983). Preistoria Alpina 33, 133-138.

Cozzaglio, A., 1934. Scoperta di nuove stazioni preistoriche nel Bresciano. Stazione di Tremosine (lago di Garda). Stazione preistorica di Verziano. Commentari dell'Ateneo di Brescia per l'anno 97-106.

Cusinato, A., Dalmeri, G., Kompatscher, K., Hrozny Kompatscher, M., 2004. Gli insiemi litici della sequenza preistorica di Riparo la Cogola e la problematica relativa alla transizione tra Epigravettiano e Mesolitico in area alpina. Preistoria Alpina 40, 125-154.

Dalmeri, G., 1982. Rinvenimento di alcune stazioni preistoriche nella zona di Storo Val Giudicarie inferiore), Trento. Preistoria Alpina 18, 163-174.

Dalmeri, G., 1985a. Laghetto di Roncone - Val Giudicarie inf. (Trento). Preistoria Alpina 21, 234. 
Dalmeri, G., 1985b. Lago di Campo - Val Daone (Trento). Preistoria Alpina 21, 235. Dalmeri, G., 1985c. Monte Peller (Dolomiti di Brenta). Preistoria Alpina 21, 273.

Dalmeri, G., 1993. Ricerche nel sito tardopaleolitico-mesolitico di Terlago (Trento). Tracce di strutture d'abitato. Natura Bresciana 28, 433-461.

Dalmeri, G., Grimaldi, S., Lanzinger, M., 2001. Il Paleolitico e il Mesolitico. In: Lanzinger, M., Marzatico, F., Pedrotti, A. (Eds.), Storia del Trentino, La Preistoria e la protostoria, vol. 1. Il Mulino, Bologna, pp. 15-117.

Dalmeri, G., Kompatscher, K., Hrozny Kompatscher, M., Bassetti, M., Cusinato, A. Piazzi, O., 2004. Dinamiche comportamentali degli ultimi cacciatori raccoglitori in area alpina. Il caso di studio del sito LR3 del Laghetto delle Regole (Castelfondo, Trento). Preistoria Alpina 40, 5-26.

Dalmeri, G., Duches, R., Rosà, V., 2008a. Nuovi ritrovamenti del Paleolitico medio sul Monte Baldo settentrionale. Preistoria Alpina 43, 5-11.

Dalmeri, G., Cusinato, A., Neri, S., Nicolodi, F., 2008b. Le industrie mesolitiche di Riparo Pradestel (Trento). Aspetti tipologici ed evolutivi. Preistori Alpina 43, 131-186.

Dalmeri, G., Cusinato, A., Kompatscher, K., Hrozny Kompatscher, M., Bassetti, M. Neri, S., 2009. The ocra painted stones from the Riparo Dalmeri (Trento) Development of the research on the art and rituality of the Epigravettian site. In: Proceedings of Hugo Obermaier Society. 49th Annual Meeting, pp. 95-119. Preistoria Alpina 44.

De Marinis, R., Pedrotti, A., 1997. L'età del Rame nel versante italiano delle Alp centro-occidentali". In: Proceedings of the meeting "La Valle d'Aosta nel quadro della preistoria e Protostoria dell'arco alpino centro-occidentale.", Courmayeur, 2-5 giugno, 1994. Istituto Italiano di Preistoria e Protostoria, Firenze, pp. $247-300$

Della Casa, P., 1995. Lo strato inferiore di Mesocco-Tec nei Grigioni (Svizzera)considerazioni sul popolamento delle vallate sud-alpine fra Mesolitico e Neolitico. Preistoria Alpina 31, 61-89.

Della Casa, P., 2001. Natural and cultural landscapes: models of Alpine land use in the Non Valley (I), Mittelbünden (CH) and Maurienne (F). Preistoria Alpina 35, $120-140$.

Della Casa, P., 2002. Discussione: risorse, territorio, società. In: Paesaggi, insediamenti, risorse. Scenari a lungo termine dell'attività umana in alcune region alpine della Svizzera, dell'Italia e della Francia, pp. 61-80. Préhistoires 6, editions Monique Mergoil, Montagnac.

Della Casa, P., 2003. Concepts of Copper Age mobility in the Alps based on land use raw materials and a framework of contact. Preistoria Alpina 39, 203-210.

Finotti, F., 1981. Note illustrative della carta geologica del Monte Baldo settentrionale. Museo Civico di Rovereto LXXXIII, Rovereto.

Fontana, F., Pasi, E., 2002. Risultati delle ultime prospezioni nell'area di Mondeval de Sora (San Vito di Cadore, Belluno), QAV XVIII, pp. 21-30.

Franco, C., 2011. La fine del Mesolitico in Italia. Identità culturale e distribuzione territoriale degli ultimi cacciatori-raccoglitori. Società per la Preistoria e Protostoria della Regione Friuli-Venzia Giulia 13 (Trieste).

Garcia, D., Mocci, F., Tzortzis, S., Walsh, K., Dumas, V., 2007. Archéologie de la vallée de l'Ubaye (Alpes-de-Haute-Provence, France): premiers résultats d'un Projet Collectif de Recherche. Preistoria Alpina 42, 23-48.

Guerreschi, A., 1984. Il sito epigravettiano di Andalo (Trento) ed alcune considerazioni sull'Epigravettiano finale nel nord Italia. Preistoria Alpina 20, 15-38.

Hafner, A., 2009. Lenk - Schnidejoch - Archäologie zwischen Gletschern und Gipfel, AS 32, 3, pp. 20-27.

Kompatscher, K., Hrozny Kompatscher, M., 2007. Dove piantare il campo: modelli insediativi e di mobilità nel Mesolitico in ambiente alpino. Preistoria Alpina 42 $137-161$.

Küster, H., 1994. Highland and lowland exploitation in the Alps: the evidence from pollen data. In: Biagi, P., Nandris, J. (Eds.), Highland zone Exploitation in Southern Europe, pp. 95-105. Natura Bresciana 20.

Laplace, G., 1964. Essai de typologie systématique. Annali Università di Ferrara XV.

Leonardi, G., Bianchini, E., Balista, C., Stabile, G., 1981. Ripresa degli scavi nella palafitta di Molina di Ledro: scavi 1980-Nota preliminare. Preistoria Alpina 39-55.

Maggi, R., 2004. L'eredità della Preistoria e la costruzione del paesaggio. In: Liguri, I. (Ed.), Un antico popolo europeo tra Alpi e Mediterraneo, pp. 34-49. Skira, Milano.

Magny, M., Joannin, S., Galop, D., Vannière, B., Haas, J.N., Bassetti, M., Bellintani, P. Scandolari, R., Desmet, M., 2012. Holocene palaeohydrological changes in the northern Mediterranean borderlands as reflected by the lake-level record of Lake Ledro, northeastern Italy. Quaternary Research 77, 382-396.

Marzatico, F., 2007. La frequentazione dell'ambiente montano nel territorio atesino fra l'età del Bronzo e del Ferro: alcune considerazioni sulla pastorizia transumante e "l'economia di malga". Preistoria Alpina 42, 163-182.
Mottes, E., 2013. Il Neolitico dell'Alto Garda: aspetti culturali e dinamiche insediative nel quadro della Preistoria del territorio sudalpino centro-orientale. In: Brogiolo, G.P. (Ed.), APSAT 3. Paesaggi storici del Sommolago, pp. 89-115. Progetti di Archeologia, Mantova.

Mottes, E., Nicolis, F., 2002. Il territorio del Trentino tra Neolitico recente ed età del Rame: analisi e interpretazione dei dati. In: Ferrari, A., Visentini, P. (Eds.), Il declino del mondo neolitico. Ricerche in Italia centro-settentrionale fra aspetti peninsulari, occidentali e nord-alpini, Quaderni del Museo Archeologico del Friuli occidentale 4, pp. 237-256.

Mottes, E., Rottoli, M., Petrucci, G., Visentini, P., 2009. Evolution of the SquareMouthed pottery Culture in Trentino Alto Adige, Veneto and Friuli: cultural, chronological, Palaeo-economic and Environmental aspects. Gortania 31, 99-124.

Mottes, E., Bassetti, M., Gavioli, J., 2014. Sito all'aperto dell'Epigravettiano recente e del Mesolitico antico ad Arco via Serafini. Archeologia delle Alpi 203-205.

Nicolis, F., Mottes, E., Degasperi, N., Conci, C., 2007. Il riparo sottoroccia di Ala Le Corone (Trento) in Valle dell'Adige. Considerazioni preliminari sulla sequenza stratigrafica e culturale. In: Il Baldo nell'antichità, atti del primo convegno di studi e di ricerche archeologiche. Rovereto, pp. 78-94.

Nisbet, R., 2004. Alcune riconsiderazioni sulla preistoria del Pinerolese: Roc del Col nel contesto alpino. In: Bertone, A., Fozzati, L. (Eds.), La civiltà di Viverone, la conquista di una nuova frontiera nell'Europa del II millennio a.C. Eventi and Progetti, Biella, pp. 109-124.

Oeggl, K., 1994. The palynological record of human impact on highland zone ecosystems. In: Highland zones exploitation in southern Europe. Natura Bresciana 20, pp. $112-121$

Palmieri, G. 1978. Monte Cernera - Cadore (Belluno). Preistoria Alpina 14, 253-254

Pedrotti, A., 1996. Un insediamento d'altura alla Torretta di Isera. In: Tecchiati, U. (Ed.), Archeologia del Comun Comunale lagarino. Storia e forme dell'insediamento dalla preistoria al Medio Evo. Rovereto, pp. 71-86.

Pedrotti, A., 2001a. Il Neolitico. In: Lanzinger, M., Marzatico, F., Pedrotti, A. (Eds.), Storia del Trentino, La Preistoria e la protostoria, vol. 1. Il Mulino, Bologna, pp. $119-181$.

Pedrotti, A., 2001b. The Neolithic Age in Trentino Alto Adige. Preistoria Alpina 34, $19-25$.

Perini, R., 1994. Scavi archeologici nella zona palafitticola di Fiavè. Servizio beni culturali della Provincia Autonoma di Tento (Trento).

Pétrequin, P., Cassen, S., Errera, M., Klassen, L., Pétrequin, A.-M., Sheridan, A., 2013. The value of things: the production and circulation of alpinejade axes during the 5 th -4 th millenia in a european perspective. In: Kerig, T., Zimmermann, A. (Eds.), Economic Archaeology: from Structure to Performance in European Archaeology, pp. 65-82. Habelt, Bonn, 2013.

Rageth, J., 1974. Der Lago di Ledro im Trentino. Bericht der Römisch-Germanischen Kommission des Deutschen Archäologischen Institus 55, pp. 73-260.

Raiteri, L., 2008-2009. La ricerca sul popolamento della Valle d'Aosta nell'Olocene antico: il sito mesolitico di alta quota del Fallère. Graduation thesis. University of Ferrara, Italy.

Reisigl, H., 2001. Geologie. Institutfür Botanik, Universität Innsbruck,Flora und Vegetation der Berge westlich des Gardasees. Führer zur Geobotanischen Bergwoche Val di Ledro. 39 pp.

Reitmaier, T., Lambers, K., Walser, C., Zingman, I., Hass, J.N., Dietre, B., Reidl, D. Hajdas, I., Nicolussi, K., Kathrein, Y., Naef, L., Kaiser, T., 2013. Alpine Archäologie in der Silvretta. Archäologie der Schweiz 36 (1), 4-14.

Riedel, A., Tecchiati, U., 1997. Rinvenimenti preistorici al Mandron de Camp Monte Baldo (Brentonico-TN) a quota 1700 m/s.l.m. In: Riassunti della "XXXIII Riunione Scientifica dell'Istituto Italiano di Preistoria e Protostoria”. Trento, 139

Scoz, L., Fedrigotti, A., 2014. Pastori + antichi in Valle di Ledro: primi dati dalle ricognizioni archeologiche. In: Avanzini, M., Salvador, I. (Eds.), Antichi Pastori. Sopravvivenze, e tradizione orale, storia, tracce nel paesaggio e archeologia. Muse Museo delle Scienze, Trento, pp. 67-77.

Scoz, L., Fedrigotti, A., Neri, S., Dalmeri, G., 2013. Prime tracce di popolamento in Valle di Ledro: l'industria litica di Pozza Lavino. Preistoria Alpina 47, 333-336. Stein, J.K., 1992. Deciphering a Shell Midden (London and San Diego).

Venturino Gambari, M., 1998. Società ed economia dal Neolitico all'età dei Metalli. In: Mercando, L., Venturino Gambari, M. (Eds.), Archeologia in Piemonte, La Preistoria, vol. I. Allemandi, Torino, pp. 231-246.

Visentin, D., Fontana, F., Cavulli, F., Carrer, F., Cesco Frare, P., Mondini, C., Pedrotti, A., 2015. Prehistoric landscapes of the Dolomites. Survey data from the highland territory of Cadore (Belluno Dolomites, North-Eastern Italy). Quaternary International (in press). 